\title{
Hydralazine Hydrochloride: An Alternative Complexometric Reagent for Total Iron Spectrophotometric Determination
}

\author{
Arlan de Assis Gonsalves ${ }^{1}$, Cleônia Roberta Melo Araújo ${ }^{1}$, Cristiane Xavier Galhardo ${ }^{2}$, \\ Marilia Oliveira Fonseca Goulart ${ }^{3}$, Fabiane Caxico de Abreu $^{3}$ \\ ${ }^{1}$ Colegiado de Ciências Farmacêuticas, Universidade Federal do Vale do São Francisco, Petrolina, Brazil \\ ${ }^{2}$ Colegiado de Engenharia Agronômica, Universidade Federal do Vale do São Francisco, Petrolina, Brazil \\ ${ }^{3}$ Instituto de Química e Biotecnologia, Universidade Federal de Alagoas, Maceió, Brazil \\ E-mail: arlangonsalves@hotmail.com \\ Received July 14, 2011; revised August 22, 2011; accepted September 3, 2011
}

\begin{abstract}
An alternative spectrophotometric method has been developed for total iron determination using flow injection analysis (FIA). The procedure is based on the coordination reaction between hydralazine and $\mathrm{Fe}^{2+}$ ions, which results in the formation of a purple complex monitored at $538 \mathrm{~nm}$. For determination of total iron, $\mathrm{Fe}^{3+}$ ions were reduced using ascorbic acid. Under optimized conditions, a linear calibration graph $(0.1-6.0$ $\left.\mu \mathrm{g} \cdot \mathrm{ml}^{-1} ; n=6\right)$ was obtained. The method allows LOD ( $3 \sigma \mathrm{of}$ blank/slope $\left.=0.06 \mu \mathrm{g} \cdot \mathrm{ml}^{-1}\right)$ and LOQ $(10 \sigma \mathrm{of}$ blank/slope $\left.=0.22 \mu \mathrm{g} \cdot \mathrm{ml}^{-1}\right)$. The RSD $((\mathrm{s} / \overline{\mathrm{x}}) \times 100)$ for a mixed standard containing $0.60 \mu \mathrm{g} \cdot \mathrm{ml}^{-1} \mathrm{Fe}^{2+}$ and $\mathrm{Fe}^{3+}$ was $0.10 \%(n=10)$. Recoveries of spiked samples were $94.3 \%-106.0 \%$. The analytical frequency was $60 \mathrm{~h}^{-1}$. The effect of possible interferences has been studied. The procedure was successfully applied for analysis of environmental samples. The real samples results were comparable with those obtained by the official method considering a paired $t$-test and $95 \%$ of confidence level.
\end{abstract}

Keywords: Hydralazine, Total Iron Determination, Spectrophotometry, Flow Injection Analysis

\section{Introduction}

The iron element $(\mathrm{Fe})$ is the fourth most abundant chemical specie of the planet and is present in nature in the following oxidation states: $\mathrm{Fe}^{2+}$ and $\mathrm{Fe}^{3+}[1]$.

Nowadays the determination of iron in some real samples cannot be considered an analytical challenge but the introduction of alternative complexing agents for this purpose it is very attractive. Some analytical procedures already employed commercial drugs to determine iron, for example: the antibiotics chlortetracycline and norfloxacin were used by Ruengsitagoon and Pojanagaroon respectively to quantify $\mathrm{Fe}^{3+}$ in real samples [1,2]. Using the same strategy, this work comes demonstrate the use of hydralazine hydrochloride for total iron determination in real samples. A list of some complexometric organic reagents not usual used for iron determination employing spectrophotometry is shown in Table $\mathbf{1}$.

Hydralazine hydrochloride (Figure 1) is an antihypertensive drug that acts as a potent arteriolar dilator and
Table 1. Some complexometric organic reagents not usual used for iron determination employing spectrophotometry.

\begin{tabular}{lccc}
\hline \multicolumn{1}{c}{ Organic Reagent } & Type of Iron & $\lambda_{\text {MAX }}(\mathrm{nm})$ & Ref. \\
\hline DPQH $^{\mathrm{a}}$ & $\mathrm{Fe}^{2+}$ & 504 & {$[3]$} \\
1,10-Phenantroline & Total $^{\mathrm{b}}$ & 510 & {$[4]$} \\
Thioglycolic acid & $\mathrm{Fe}^{3+}$ & 535 & {$[5]$} \\
DPPH $^{\mathrm{a}}$ & $\mathrm{Fe}^{2+}$ and Fe $^{3+\mathrm{c}}$ & 535 & {$[6]$} \\
5-Br-PSAA & & 558 & {$[7]$} \\
Nitro-PAPS $^{\mathrm{a}}$ & Total $^{\mathrm{b}}$ & 582 & {$[8]$} \\
Tiron $^{\mathrm{a}}$ & Total $^{\mathrm{b}}$ & 635 & {$[9]$} \\
DPKBH $^{\mathrm{a}}$ & Total $^{\mathrm{d}}$ and Fe $^{3+}$ & 686 & {$[10]$} \\
DPFTH $^{\mathrm{a}}$ & Total $^{\mathrm{b}}$ & 738 & {$[11]$} \\
TLCR $^{\mathrm{a}}$ & Total $^{\mathrm{b}}$ & 741 & {$[12]$} \\
\hline
\end{tabular}

${ }^{\mathrm{a}} \mathrm{See}$ list of acronyms in section 10 of this paper; ${ }^{\mathrm{b}}$ Total iron expressed as $\mathrm{Fe}^{2+}$ after a reduction of $\mathrm{Fe}^{3+}$; ${ }^{\mathrm{c}}$ Conversion of $\mathrm{Fe}^{3+}$ to $\mathrm{Fe}^{2+}$ with a reduction agent; ${ }^{\mathrm{d}}$ Total iron expressed as $\mathrm{Fe}^{3+}$ after an oxidation of $\mathrm{Fe}^{2+}$. 
<smiles>NNc1nncc2ccccc12</smiles>

Figure 1. Chemical structure of hydralazine hydrochloride (1-hydrazinophthalazine monohydrochloride).

also is used in the treatment of congestive heart failure [13]. It is a white powder, soluble in water with a $\mathrm{pKa}$ value of 7.3 [14]. This drug demonstrates redox properties (acting as a reducing agent) [14], antioxidant activity [15] and coordination capacity toward some metal cations [16]. Up to now and at the best of our knowledge, no report of spectrophotometric procedure using hydralazine as the chromogenic reagent for determination of metal ions has been available in literature.

Before the facts stated, this paper describes the development of a simple, rapid and sensitive flow injection method for total iron determination using hydralazine as an alternative chromogenic reagent. The proposed procedure is based on the spectrophotometric detection of the purple complex formed by the coordination reaction between hydralazine and $\mathrm{Fe}^{2+}$ ions in neutral media. The resulting complex is monitored at $538 \mathrm{~nm}$. The developed method was successfully applied for determination of total iron, after the reduction of $\mathrm{Fe}^{3+}$ into $\mathrm{Fe}^{2+}$ ions using ascorbic acid, in samples of drinking, tap and lagoon waters, besides lagoon sediments.

\section{Equipments}

An UV/Vis spectrophotometer (Femto $\AA$, model 700 Plus, Brazil) equipped with a $20 \mathrm{~mm}$ "U" glass flow cell was used as a detector in all FIA experiments, and the absorbance signal was obtained directly from the instrument. A multichannel peristaltic pump (Watson Marlow ${ }^{\circledR}$, model 400 Sci-Q, United States), a manual injector (made of acrylic, with two fixed sidebars and a sliding central bar), pump tubes (Tygon $\AA$, model R-3603, $1.02 \mathrm{~mm}$ i.d.) and polyethylene tubes (1.0 $\mathrm{mm}$ i.d.) were also used in the proposed flow injection system.

\section{Reagents and Solutions}

All chemicals were of analytical reagent grade and were used without further purifications. Hydralazine hydrochloride was acquired from Sigma (St. Louis, USA). Deionized water from a Milli-Q system (resistivity 18 $\mathrm{M} \Omega \mathrm{cm}$ ) was used for preparation of reagents and buffers. A stock solution containing $5.0 \mathrm{mmol} \cdot \mathrm{l}^{-1} \mathrm{HCl}$, prepared from concentrate hydrochloric acid (Vetec, Rio de Ja- neiro) was used for preparation of all standard solutions, and for dissolution and dilution of all real samples.

A stock solution containing $0.01 \mathrm{~mol} \cdot 1^{-1}$ hydralazine hydrochloride was prepared by dissolving $0.1000 \mathrm{~g}$ of $\mathrm{C}_{8} \mathrm{H}_{8} \mathrm{~N}_{4} \cdot \mathrm{HCl}$ in $50 \mathrm{ml}$ of deionized water.

A stock solution containing $0.15 \mathrm{~mol} \cdot \mathrm{l}^{-1}$ buffer $\mathrm{NaH}_{2} \mathrm{PO}_{4} / \mathrm{Na}_{2} \mathrm{HPO}_{4}$ (pH 7.0) was prepared by dissolving $5.2000 \mathrm{~g}$ of $\mathrm{NaH}_{2} \mathrm{PO}_{4} \cdot \mathrm{H}_{2} \mathrm{O}$ (Vetec, Rio de Janeiro) and $6.7000 \mathrm{~g}$ of $\mathrm{Na}_{2} \mathrm{HPO}_{4} \cdot 2 \mathrm{H}_{2} \mathrm{O}$ (Vetec, Rio de Janeiro) in $250 \mathrm{ml}$ of deionized water. After that, the buffer working solution was prepared by dilution of $50 \mathrm{ml}$ of the stock solution in $100 \mathrm{ml}$ of deionized water with $\mathrm{pH}$ previously adjusted to 7.0 with $1.0 \mathrm{~mol} \cdot \mathrm{l}^{-1} \mathrm{HCl}$ solution using a pHmeter.

Finally, the reagent solution (chromogenic reagent) was prepared by mixing $10 \mathrm{ml}$ of the hydralazine stock solution and $20 \mathrm{ml}$ of the buffer working solution into $100 \mathrm{ml}$ of deionized water. So, the final concentration of the hydralazine at this solution was $1.0 \mathrm{mmol} \cdot \mathrm{l}^{-1}$.

A stock solution containing ascorbic acid $1.0 \% \mathrm{w} \cdot \mathrm{v}^{-1}$ was prepared by dissolving $0.5000 \mathrm{~g}$ of this reagent (Sigma, St Louis) in $50 \mathrm{ml}$ of deionized water. So, the ascorbic acid $0.1 \% \mathrm{w}^{\cdot} \mathrm{v}^{-1}$ working solution was obtained by appropriate dilution of the stock solution in deionized water. The ascorbic acid stock solution was prepared every week and was kept in dark bottles and under refrigeration.

A stock solution containing $100 \mu \mathrm{g} \cdot \mathrm{ml}^{-1} \mathrm{Fe}^{2+}$ was prepared by dissolving $0.4980 \mathrm{~g}$ of $\mathrm{FeSO}_{4} \cdot 7 \mathrm{H}_{2} \mathrm{O}$ (Vetec, Rio de Janeiro) in $1000 \mathrm{ml}$ of $\mathrm{HCl} 5.0 \mathrm{mmol} \cdot \mathrm{l}^{-1}$. In the same way, a stock solution containing $100 \mu \mathrm{g} \cdot \mathrm{ml}^{-1} \mathrm{Fe}^{3+}$ was also prepared by dissolving $0.2904 \mathrm{~g}$ of $\mathrm{FeCl}_{3}$ (Vetec, Rio de Janeiro) in $1000 \mathrm{ml}$ of $\mathrm{HCl} 5.0 \mathrm{mmol} \cdot \mathrm{l}^{-1}$. The standard working solutions were prepared by appropriate dilution of these stock solutions in $\mathrm{HCl} 5.0 \mathrm{mmol} \cdot \mathrm{l}^{-1}$. All the stock solutions were prepared every week and the working solutions every day.

\section{Flow Injection Manifold and Procedure}

The flow injection manifold used for total iron determination can be seen in Figure 2. At this flow system, the

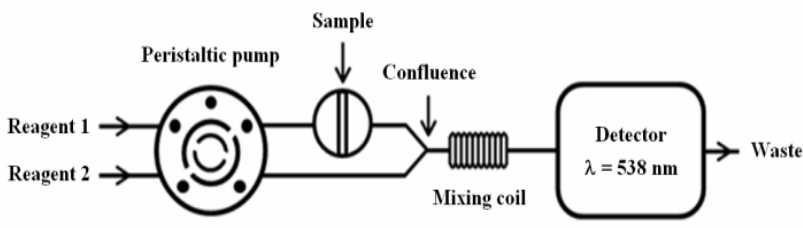

Figure 2. Flow injection manifold for total iron determination. Experimental conditions: reagent 1 (hydralazine 1.0 mmol $\cdot{ }^{-1}$ in buffer $\mathrm{NaH}_{2} \mathrm{PO}_{4} / \mathrm{Na}_{2} \mathrm{HPO}_{4} \mathrm{pH} 7.0$ ), reagent 2 (ascorbic acid $\left.0.1 \% \mathrm{w}^{\cdot} \mathrm{v}^{-1}\right)$, peristaltic pump $\left(0.9 \mathrm{ml} \cdot \mathrm{min}^{-1}\right)$, sample volume $(200 \mu \mathrm{l})$ and mixing coil $(30 \mathrm{~cm})$. 
chromogenic reagent acts as the proper carrier solution. The peristaltic pump drives the solutions forward, at the same time, the reagent 1 (hydralazine $1.0 \mathrm{mmol} \cdot \mathrm{l}^{-1}$ in buffer $\mathrm{NaH}_{2} \mathrm{PO}_{4} / \mathrm{Na}_{2} \mathrm{HPO}_{4} \mathrm{pH}$ 7.0) into the injection valve and the reagent 2 (ascorbic acid $0.1 \% \mathrm{w} \cdot \mathrm{v}^{-1}$ ) into the confluence. After this, an aliquot of the standard or the real sample is injected into the carrier stream and meets the reagent 2 in the confluence before the mixing coil. From this point, the resulting stream follows to detector and the analytical signal generated by the $\mathrm{Fe}^{2+}$-hydralazine complex is finally observed. After attaining the signal maximum, the central bar of the injection valve is moved back to the sampling position to start another measurement cycle.

\section{Samples Preparation}

Drinking water was acquired in local markets. Tap water was collected in some points of the Federal University of Alagoas (Maceió, Alagoas, Brazil). Samples of water and sediments were from Mundaú Lagoon (Maceió, Alagoas, Brazil) and were collected in different points of this estuary. Before the analysis of the water samples, all of them were previously acidified and preserved during $24 \mathrm{~h}$ with $\mathrm{HCl} 1.0 \mathrm{~mol} \cdot \mathrm{l}^{-1}$. In this procedure, the water sample was initially filtered through a $45 \mu \mathrm{m}$ glass fiber membrane filter. In a $100 \mathrm{ml}$ volumetric flask the water sample was acidified with $500 \mu \mathrm{lof} \mathrm{HCl} 1.0 \mathrm{~mol} \cdot \mathrm{l}^{-1}$, and the final volume was completed with the real sample. Some of these samples were adequately diluted before the determination of total iron.

Approximately $1.20 \mathrm{~g}$ of dry sediment of the Mundaú lagoon was treated with $\mathrm{HCl} 0.1 \mathrm{~mol} \cdot \mathrm{l}^{-1}$. The resulting acid solution was shaken during 2 hours at $200 \mathrm{rpm}$, and filtered through a $45 \mu \mathrm{m}$ glass fiber membrane filter into a $50 \mathrm{ml}$ volumetric flask, which final volume was completed with deionized water.

\section{Results and Discussion}

\subsection{Absorption Spectra and Metal:Ligand Ratio}

The absorption spectrum of the purple complex obtained by coordination reaction between $\mathrm{Fe}^{2+}$ ions and hydralazine was measured over the range of $400-600 \mathrm{~nm}$ using a spectrophotometer. The absorption maximum of the complex was $538 \mathrm{~nm}$. In order to achieve the greatest sensitivity, measurements were made at this wavelength.

The metal-to-ligand ratio $\left(\mathrm{Fe}^{2+}\right.$ :hydralazine) was determined by the Job's method (continuous variation method) and was found to be 1:2 at $\mathrm{pH} 7.0$, as shown in Figure 3. The stoichiometry was verify remained the plus of concentrations of the metal and ligand constant, however each plus differ one each other $\left(\mathrm{C}_{\mathrm{Fe}}+\mathrm{C}_{\mathrm{hid}}=0.4\right.$ $\mathrm{mmol} \cdot \mathrm{l}^{-1} ; \mathrm{C}_{\mathrm{Fe}}+\mathrm{C}_{\mathrm{hid}}=0.3 \mathrm{mmol} \cdot \mathrm{l}^{-1} ; \mathrm{C}_{\mathrm{Fe}}+\mathrm{C}_{\mathrm{hid}}=0.2$ $\left.\mathrm{mmol} \cdot 1^{-1} ; \mathrm{C}_{\mathrm{Fe}}+\mathrm{C}_{\mathrm{hid}}=0.1 \mathrm{mmol} \cdot \mathrm{1}^{-1}\right)$.

\subsection{Optimization of the Flow Injection System}

The physical parameters optimization of the flow injection system was conducted employing standard solutions of $\mathrm{Fe}^{2+}\left(1.0 \mu \mathrm{g} \cdot \mathrm{ml}^{-1}\right)$, since the proposed method determines total iron by reduction of $\mathrm{Fe}^{3+}$ to $\mathrm{Fe}^{2+}$. In these studies, the effect of sample volume and mixing coil length were evaluated to reach the best conditions of analysis. Different sample loop lengths were tested: 10, $15,20,25,30$ and $40 \mathrm{~cm}$ with volumes of 100, 150, 200, 250, 300 and $400 \mu \mathrm{L}$, respectively. Various mixing coil tubing lengths: 20, 30, 40, 50 and $70 \mathrm{~cm}$ was also studied. The parameters were compared in terms of peak height and precision. Among the evaluated parameters the most suitable injection loop volume was $200 \mu \mathrm{l}$, and because of the higher signal the mixing coil of $30 \mathrm{~cm}$ was also chosen for next studies.

The following chemical parameters of the flow injection system were also studied: hydrochloric acid concentration, hydralazine concentration, ascorbic acid concentration, effect of the $\mathrm{Fe}^{3+}$ concentration in the reduction step and $\mathrm{pH}$ of the reaction media. In all of these cases, the chosen of the concentration and the $\mathrm{pH}$ was made considering the studied value that produced the maximum absorbance signal (in order to obtain greatest sensitivity) and the lowest Schlieren effect. The Table 2 summarizes the optimum conditions of all studied parameters in the proposed flow injection method for total iron determination.

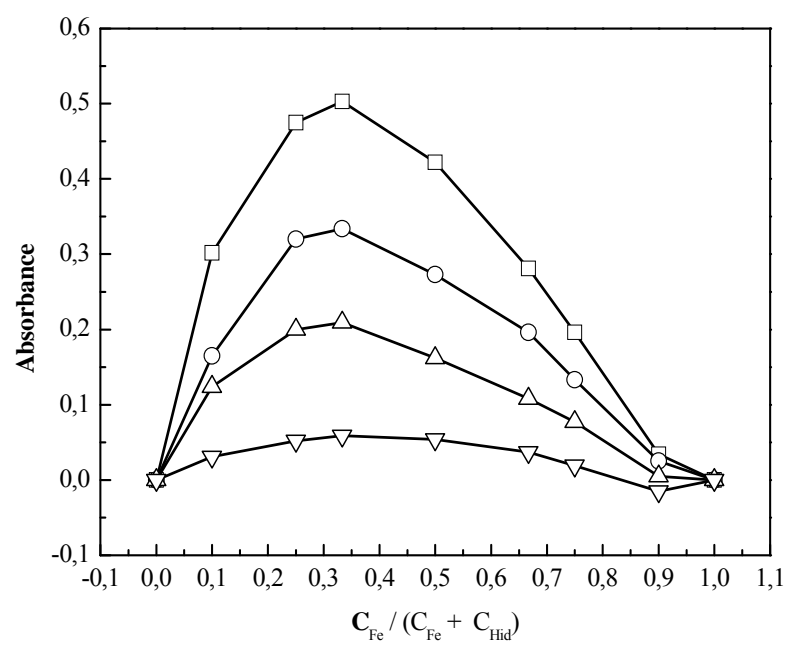

Figure 3. Job's method for the study of complexation of hydralazine and $\mathrm{Fe}^{2+}$ ions at $\mathrm{pH}$ 7.0. $\left(\mathrm{C}_{\mathrm{Fe}}+\mathrm{C}_{\mathrm{hid}}=k\right)$ with $\boldsymbol{k}=$ $0.4 \mathrm{mmol} \cdot \mathrm{I}^{-1}(\square) ; \boldsymbol{k}=0.3 \mathrm{mmol} \cdot \mathrm{l}^{-1}(O) ; \boldsymbol{k}=0.2 \mathrm{mmol} \cdot \mathrm{I}^{-1}(\triangle)$; $k=0.1 \mathrm{mmol} \cdot \mathrm{I}^{-1}(\nabla)$. 
Table 2. Physical and chemical parameters for flow injection determination of total iron.

\begin{tabular}{lcc}
\multicolumn{1}{c}{ Parameters $^{\mathrm{a}}$} & $\begin{array}{c}\text { Studied } \\
\text { Range }\end{array}$ & $\begin{array}{c}\text { Optimum } \\
\text { Value }\end{array}$ \\
\hline Physical: & $400-600$ & 538 \\
Wavelength $(\mathrm{nm})$ & $20-70$ & 30 \\
Mixing coil length $(\mathrm{cm})$ & $100-400$ & 200 \\
Sample injection volume $(\mu \mathrm{l})$ & & 1.0 \\
Chemical: & $0.5-8.0$ & 0.1 \\
Hydralazine concentration $\left(\mathrm{mmol} \cdot \mathrm{l}^{-1}\right)$ & $0.01-0.2$ & 5.0 \\
Ascorbic acid concentration $\left(\% \mathrm{w}^{\circ} \mathrm{v}^{-1}\right)$ & $1.0-100$ & 7.0 \\
HCl concentration $\left(\mathrm{mmol}^{-1}\right)$ & $6.2-8.2$ & \\
pH $\left(\mathrm{NaH}{ }_{2} \mathrm{PO}_{4} / \mathrm{Na}_{2} \mathrm{HPO}_{4}\right.$ buffer $)$ &
\end{tabular}

${ }^{\mathrm{a}}$ Studied only at room temperature $\left(25^{\circ} \mathrm{C}\right)$.

\section{Method Validation}

The calibration curve was obtained employing mixed standards containing the same amounts of $\mathrm{Fe}^{2+}$ and $\mathrm{Fe}^{3+}$. Under the optimum conditions, the graph was found to be linear over the range of $0.1-6.0 \mu \mathrm{g} \cdot \mathrm{ml}^{-1}$. This short range is due to the previously discussed reduction step. To determine total iron in real samples, six mixed standards were employed, containing $0.05,0.1,0.2,0.4,0.7$ and $1.0 \mu \mathrm{g} \cdot \mathrm{ml}^{-1}$ of $\mathrm{Fe}^{2+}$ and $\mathrm{Fe}^{3+}$, so leading to concentrations of $0.1,0.2,0.4,0.8,1.4$ and $2.0 \mu \mathrm{g} \cdot \mathrm{ml}^{-1}$ of total iron. The regression plot obtained for total iron determination fitted the equation: $\mathrm{A}=0.0325 C-0.0013(\mathrm{r}=$ $0.9990, n=6$ ), where $\mathrm{A}$ is the signal (in absorbance) and $\mathrm{C}$ the concentration of total iron $\left(\mu \mathrm{g} \cdot \mathrm{ml}^{-1}\right)$. The limit of detection (LOD) obtained by the proposed method defined as $3 \sigma / 0.0325$ and the limit of quantification (LOQ) defined as $10 \sigma / 0.0325$ was 0.06 and $0.22 \mu \mathrm{g} \cdot \mathrm{ml}^{-1}$ respectively, where $\sigma$ is the standard deviation of the blank signal $(n=10)$ and 0.0325 is the slope of the calibration curve [17].

The relative standard deviation (peak height in absorbance; $(\mathrm{s} / \overline{\mathrm{x}}) \times 100)$ calculated from 10 replicate injections of a mixed standard containing $0.60 \mu \mathrm{g} \cdot \mathrm{ml}^{-1} \mathrm{Fe}^{2+}$ and $\mathrm{Fe}^{3+}$ was $0.10 \%$. Considering the optimum conditions of the proposed flow injection system, a maximum sample throughput of $60 \mathrm{~h}^{-1}$ was obtained without any carryover effect.

\subsection{Interference Studies}

The effects of potential interfering ions were examined by using solutions containing $1.0 \mu \mathrm{g} \cdot \mathrm{ml}^{-1} \mathrm{Fe}^{2+}$ and the ionic species evaluated at different concentrations. The ions selected for this study were those usually found in water samples besides some metal cations. The tolerable concentration of each different ion was taken as a highest concentration causing a relative error of $\pm 5.0 \%$. The results were summarized in Table 3. Most of the ions examined did not interfere with the determination of iron. Copper was found to seriously interfere in the determination of iron when its concentration reaches $0.5 \mu \mathrm{g} \mathrm{ml}^{-1}$. The positive interference observed when $\mathrm{Cu}^{2+}$ is present in samples is probably due to the formation of a complex between this metal cation and hydralazine that also absorbs electromagnetic radiation next to $538 \mathrm{~nm}$.

To eliminate the $\mathrm{Cu}^{2+}$ interference in analyses was used a liquid-liquid extraction method developed by Faquim and Munita [18]. Adapting this procedure for the purposes of this work, an organic solution of dithizone (diphenylthiocarbazone) was used to extract selectively $\mathrm{Cu}^{2+}$ ions from aqueous standard solutions containing $\mathrm{Fe}^{2+}, \mathrm{Fe}^{3+}$ and $\mathrm{Cu}^{2+}$ ions. The procedure consisted in treat, previously of analyses, $50.0 \mathrm{ml}$ of the aqueous standard solutions with $5.0 \mathrm{ml}$ of an extraction solution containing $1.0 \mathrm{mmol}^{-1}$ of dithizone in chloroform. The standard solutions were prepared always containing $1.0 \mu \mathrm{g} \cdot \mathrm{ml}^{-1}$ $\mathrm{Fe}^{2+} \mathrm{e} \mathrm{Fe}^{3+}$ and different concentrations of $\mathrm{Cu}^{2+}(1.0,2.0$, 3.0 e $4.0 \mu \mathrm{g} \cdot \mathrm{ml}^{-1}$ ). In treatment, the aliquots of the extraction solution were added to the standards and then,

Table 3. Effect of chosen ions on the peak height of $1.0 \mu \mathrm{g}$ $\mathrm{ml}^{-1} \mathrm{Fe}^{2+}$ standard solution $(n=3)$.

\begin{tabular}{cc}
\hline $\begin{array}{c}\text { Ionic Species } \\
\left.\text { (concentration in } \mu \mathrm{g} \cdot \mathrm{ml}^{-1}\right)\end{array}$ & $\begin{array}{c}\text { Relative Percentage of } \\
\text { Peak Height }(\%)\end{array}$ \\
\hline None & 100.0 \\
Cations: & 94.2 \\
$\mathrm{Na}^{+}(150)$ & 102.8 \\
$\mathrm{~K}^{+}(150)$ & 98.5 \\
$\mathrm{Mg}^{2+}(300)$ & 102.0 \\
$\mathrm{Ca}^{2+}(25)$ & 105.4 \\
$\mathrm{Cu}^{2+}(0.5)$ & 103.5 \\
$\mathrm{Cd}^{2+}(5)$ & 102.7 \\
$\mathrm{~Pb}^{2+}(10)$ & \\
$\mathrm{Anions}^{2}$ & 98.9 \\
$\mathrm{Cl}^{-}(50)$ & 102.8 \\
$\mathrm{NO}_{2}^{-}(10)$ & 101.5 \\
$\mathrm{NO}_{3}^{-}(50)$ & 101.0 \\
$\mathrm{CO}_{3}^{2-}(10)$ & 102.4 \\
$\mathrm{SO}_{4}^{2-}(5)$ & 98.3 \\
$\mathrm{PO}_{4}^{3-}(25)$ & \\
& \\
\hline
\end{tabular}


the resulting mixture remained under vigorous agitation during 5 minutes. Finalized the time, waited the organic phase decant and then, the aqueous phase was collected with a syringe to be analyzed in the proposed flow system. Comparing the spectrophotometric signals in analyses of the standards before and after the treatment with dithizone was verified that the procedure was efficient to eliminate or reduce the interference of $\mathrm{Cu}^{2+}$ ions present until the concentration of $3.0 \mu \mathrm{g} \cdot \mathrm{ml}^{-1}$, a fact verified by checking the relative percentage of peak height of the standards containing $1.0(100 \%), 2.0(101.2 \%), 3.0$ $(104.8 \%)$ and $4.0(108.6 \%) \mu \mathrm{g} \cdot \mathrm{ml}^{-1}$ of $\mathrm{Cu}^{2+}$ ions.

\subsection{Analysis of Total Iron in Real Samples}

The proposed flow injection method was applied to tap and drinking water and also natural water besides sediments from Mundaú lagoon. When the obtained results, showed in Table 4, were compared with those obtained by using 1,10-phenanthroline spectrophotometric method [19], it was seen that the proposed procedure provide good results, and no statistical difference was found considering the paired $t$-test at the $95 \%$ confidence level [17].

The good agreement between the results of the concentration of total iron measured as $\mathrm{Fe}^{2+}$ using the standard and proposed methods is showed in Figure 4. The value obtained from linear regression showed that the intercept including $0(0.002 \pm 0.02)$ and the slope including $1(0.98 \pm 0.02)$ [17]. The proposed method using hydralazine as chromogenic reagent was efficient for the determination of tap and lagoon water.

Table 4. Determination of total iron by the proposed flow injection method and standard method.

\begin{tabular}{lcc}
\hline & \multicolumn{1}{c}{ Total Iron Found $\left(\mu \mathrm{g} \cdot \mathrm{ml}^{-1}\right.$ or $\left.\mathrm{g} \cdot \mathrm{kg}^{-1}\right)$} \\
\cline { 2 - 3 } \multicolumn{1}{c}{ Samples } & Proposed FI \\
Method & $\begin{array}{c}\text { Standard } \\
\text { Method }\end{array}$ \\
\hline Tap water $1\left(\mathrm{w} \cdot \mathrm{v}^{-1}\right)$ & $1.09 \pm 0$ & $1.07 \pm 0.02$ \\
Tap water $2\left(\mathrm{w} \cdot \mathrm{v}^{-1}\right)$ & $0.75 \pm 0$ & $0.73 \pm 0$ \\
Tap water $3\left(\mathrm{w} \cdot \mathrm{v}^{-1}\right)$ & $1.27 \pm 0$ & $1.28 \pm 0$ \\
Tap water $4\left(\mathrm{w} \cdot \mathrm{v}^{-1}\right)$ & $1.67 \pm 0$ & $1.62 \pm 0$ \\
Lagoon water $1\left(\mathrm{w} \cdot \mathrm{v}^{-1}\right)$ & $1.26 \pm 0.02$ & $1.22 \pm 0.02$ \\
Lagoon water $2\left(\mathrm{w} \cdot \mathrm{v}^{-1}\right)$ & $0.83 \pm 0$ & $0.82 \pm 0.01$ \\
Lagoon water $3\left(\mathrm{w} \cdot \mathrm{v}^{-1}\right)$ & $0.70 \pm 0.02$ & $0.68 \pm 0.01$ \\
Lagoon water $4\left(\mathrm{w} \cdot \mathrm{v}^{-1}\right)$ & $0.98 \pm 0.04$ & $0.95 \pm 0$ \\
Lagoon sediment $1\left(\mathrm{w} \cdot \mathrm{w}^{-1}\right)$ & $42.5 \pm 0.83$ & $44.0 \pm 0.52$ \\
Lagoon sediment $2\left(\mathrm{w} \cdot \mathrm{w}^{-1}\right)$ & $70.8 \pm 1.02$ & $68.5 \pm 0.95$ \\
Lagoon sediment $3\left(\mathrm{w} \cdot \mathrm{w}^{-1}\right)$ & $65.8 \pm 0.67$ & $66.0 \pm 0.80$ \\
Lagoon sediment $4\left(\mathrm{w} \cdot \mathrm{w}^{-1}\right)$ & $48.9 \pm 1.61$ & $47.0 \pm 0.72$ \\
\hline
\end{tabular}

\subsection{Recovery Studies}

In order to estimate the accuracy of the procedure, different amounts of $\mathrm{Fe}^{2+}$ and $\mathrm{Fe}^{3+}$ were spiked in samples of drinking and tap water. Samples of water and sediments from Mundaú Lagoon (Maceió, Alagoas, Brazil) were also investigated. The results are given in Table 5. A good agreement was obtained between the added and measured analyte amounts. The average recoveries of total iron for added standards were superior to $99 \%$, thus confirming the accuracy of the proposed procedure. Recoveries above and below $105 \%$ and $95 \%$, respectively, may be due to interference from other elements in the samples, since complex matrices were analyzed.

\section{Conclusions}

A spectrophotometric method using FIA for total iron determination employing hydralazine was developed.

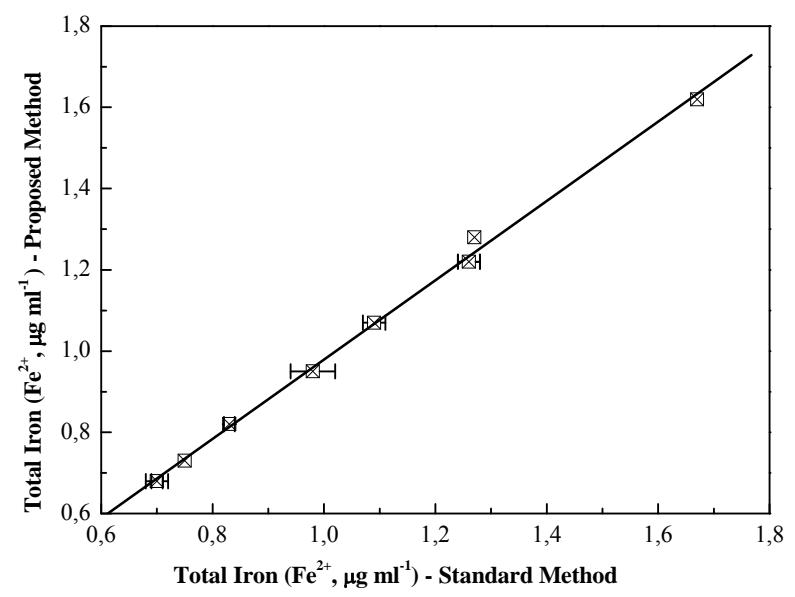

Figure 4. Correlation between the proposed and standard methods for total iron determination in water samples.

Table 5. Recoveries of total iron from drinking, tap and lagoon water and extracts of lagoon sediments.

\begin{tabular}{ccccc}
\hline Samples & \multicolumn{2}{c}{$\begin{array}{c}\text { Added }\left(\mu \mathrm{g} \cdot \mathrm{ml}^{-1}\right) \\
\mathrm{Fe}^{2+}\end{array}$} & $\begin{array}{c}\mathrm{Fe}^{3+} \\
\left(\mu \mathrm{g} \cdot \mathrm{ml}^{-1}\right)\end{array}$ & $\begin{array}{c}\text { Recovery } \\
(\%)\end{array}$ \\
\hline Drinking water 1 & 1.00 & 0.80 & 1.88 & 104.4 \\
Drinking water 2 & 0.80 & 1.00 & 1.83 & 101.7 \\
Drinking water 3 & 0.80 & 0.80 & 1.65 & 103.1 \\
Tap water 1 & 0.60 & 0.80 & 1.32 & 94.3 \\
Tap water 2 & 0.50 & 0.50 & 1.06 & 106.0 \\
Lagoon water 1 & 0.60 & 0.40 & 1.05 & 105.0 \\
Lagoon water 2 & 0.20 & 0.40 & 0.58 & 96.7 \\
Extract of lagoon & 0.50 & 0.50 & 1.06 & 106.0 \\
sediment 1 & & & &
\end{tabular}


The procedure showed to be accurate, precise and sensitive for the analyte determination in some environmental samples. Disadvantages of the proposed method were the difficult to make the speciation between $\mathrm{Fe}^{2+}$ and $\mathrm{Fe}^{3+}$ and the significant interference of $\mathrm{Cu}^{2+}$ ions when it is present up to $0.5 \mu \mathrm{g} \cdot \mathrm{ml}^{-1}$ in samples. Despite these disadvantages, the use of hydralazine as an alternative chromogenic reagent, a commercial drug of low cost and easily acquisition, still ensures the applicability of the procedure in chemical analysis of total iron.

\section{Acknowledgements}

Financial support from $\mathrm{CNPq}, \mathrm{CNPq} / \mathrm{CTHIDRO}$, CAPES and FAPEAL (Brazil) is gratefully acknowledged. A DTI/CNPq fellowship for C. X. Galhardo is acknowledged.

\section{References}

[1] W. Ruengsitagoon, "Reverse Flow Injection Spectrophotometric Determination of Iron(III) Using Chlortetracycline Reagent," Talanta, Vol. 74, No. 5, 2008, pp. 12361241. doi:10.1016/j.talanta.2007.08.031

[2] T. Pojanagaroon, S. Watanesk, V. Rattanaphani and S. Liawrungrath, "Reverse Flow Injection Spectrophotometric Determination of Iron (III) Using Norfloxacin," Talanta, Vol. 58, No. 6, 2002, pp. 1293-1300. doi:10.1016/S0039-9140(02)00420-4

[3] M. Otomo, S. Ano and H. Kako, "Solvent Extraction and Spectrophotometric Determination of Iron(II) with 2,2'Dipyridyl-2-Quinolylhydrazone," Microchemical Journal, Vol. 26, No. 2, 1981, pp. 228-235. doi:10.1016/0026-265X(81)90094-1

[4] D. M. C. Gomes, M. A. Segundo, J. L. F. C. Lima and A. O. S. S. Rangel, "Spectrophotometric Determination of Iron and Boron in Soil Extracts Using a Multi-Syringe Flow Injection System," Talanta, Vol. 66, No. 3, 2005, pp. 703-711. doi:10.1016/j.talanta.2004.12.011

[5] M. G. Gioia, A. M. Di Pietra and R. Gatti, "Validation of a Spectrophotometric Method for the Determination of Iron (III) Impurities in Dosage Forms," Journal of Pharmaceutical and Biomedical Analysis, Vol. 29, No. 6, 2002, pp. 1159-1164. doi:10.1016/S0731-7085(02)00170-X

[6] D. G. Themelis, P. D. Tzanavaras, F. S. Kika and M. C. Sofoniou, "Flow-Injection Manifold for the Simultaneous Spectrophotometric Determination of $\mathrm{Fe}(\mathrm{II})$ and $\mathrm{Fe}$ (III) Using 2,2'-Dipyridyl-2-Pyridylhydrazone and a SingleLine Double Injection Approach," Fresenius Journal of Analytical Chemistry, Vol. 371, No. 3, 2001, pp. 364-368. doi:10.1007/s002160100930

[7] S. Ohno, N. Teshima, T. Sakai, K. Grudpan and M. Polasek, "Sequential Injection Lab-on-Valve Simultaneous Spectrophotometric Determination of Trace Amounts of Copper and Iron," Talanta, Vol. 68, No. 3, 2006, pp. 527-

\section{4. doi:10.1016/j.talanta.2005.04.073}

[8] K. A. Riganakos and P. G. Veltsistas, "Comparative Spectrophotometric Determination of the Total Iron Content in Various White and Red Greek Wines," Chemistry, Vol. 82, No. 4, 2003, pp. 637-643.

[9] M. Kass and A. Ivaska, "Spectrophotometric Determination of Iron(III) and Total Iron by Sequential Injection Analysis," Talanta, Vol. 58, No. 6, 2002, pp. 1131-1137. doi:10.1016/S0039-9140(02)00439-3

[10] T. Nakanishi and M. Otomo, "Solvent Extraction and Spectrophotometric Determination of Iron(II) with di-2Pyridyl Ketone Benzoylhydrazone," Microchemical Journal, Vol. 33, No. 2, 1986, pp. 172-178. doi:10.1016/0026-265X(86)90051-2

[11] T. Nakanishi and M. Otomo, "Solvent Extraction and Spectrophotometric Determination of Iron(II) with 2,2'Dipyridyl-2-Furancarbothiohydrazone," Microchemical Journal, Vol. 28, No. 1, 1983, pp. 99-106. doi:10.1016/0026-265X(83)90034-6

[12] K. Ueda, O. Yoshimura and Y. Yamamoto, "Rapid Spectrophotometric Determination of Iron in Natural Waters with 4-(2-Thiazolylazo)-6-Chlororesorcinol," Microchemical Journal, Vol. 31, No. 3, 1985, pp. 403-409. doi:10.1016/0026-265X(85)90134-1

[13] Y. Xiong, H. Zhou, Z. Zhang, D. He and C. He, "Determination of Hydralazine with Flow Injection Chemiluminescence Sensor Using Molecularly Imprinted Polymer as Recognition Element," Journal of Pharmaceutical and Biomedical Analysis, Vol. 41, No. 3, 2006, 694-700. doi:10.1016/j.jpba.2006.01.008

[14] S. Imad, S. Nisar and Z. T. Maqsood, "A Study of Redox Properties of Hydralazine Hydrochloride, an Antihypertensive Drug," Journal of Saudi Chemical Society, Vol. 14, No. 3, 2010, pp. 241-245. doi:10.1016/j.jscs.2010.02.003

[15] A. Daiber, A. Mülsch, U. Hink, H. Mollnau, A. Warnholtz, M. Oelze and T. Münzel, "The Oxidative Stress Concept of Nitrate Tolerance and the Antioxidant Properties of Hydralazine," The American Journal of Cardiology, Vol. 96, No. 7, 2005, pp. 25-36. doi:10.1016/j.amjcard.2005.07.030

[16] A. A. Shoukry and M. M. Shoukry, "Coordination Properties of Hydralazine Schiff Base: Synthesis and Equilibrium Studies of Some Metal Ion Complexes," Spectrochimica Acta Part A: Molecular and Biomolecular Spectroscopy, Vol. 70, No. 3, 2008, pp. 686-691. doi:10.1016/j.saa.2007.08.022

[17] J. C. Miller and J. N. Miller, "Statistics for Analytical Chemistry," Ellis Horwood, New York, 1993.

[18] E. S. Faquim and C. S. Munita, "Determination of Copper by Isotopic Dilution," Biological Trace Element Research, Vol. 43, No. 1, 1994, pp. 669-677. doi:10.1007/BF02917370

[19] J. W. Stucki and W. L. Anderson, "The Quantitative Assay of Minerals for $\mathrm{Fe}^{2+}$ and $\mathrm{Fe}^{3+}$ Using 1,10-Phenanthroline: I. Sources of Variability," Soil Science Society of America Journal, Vol. 45, No. 3, 1981, pp. 633-637. doi:10.2136/sssaj1981.03615995004500030039x 


\section{Acronyms}

The Table 6 shows a list of acronyms and its respective meanings used in this paper.

Table 6. List of acronyms used in this paper.

\begin{tabular}{ll}
\hline Acronyms & \multicolumn{1}{c}{ Meanings } \\
\hline DPQH & 2,2'-Dipyridyl-2-quinolylhydrazone \\
DPPH & 2,2'-Dipyridyl-2-pyridylhydrazone \\
5-Br-PSA & $\begin{array}{l}\text { 2-(5-Bromo-2-pyridylazo)-5-[ } N \text { - } n \text {-propyl- } N \text {-(3 } \\
\text { A }\end{array}$ \\
-sul-fopropyl)-amino]aniline \\
Nitro-PAP & $\begin{array}{l}\text { 2-(5-Nitro-2-pyridylazo)-5-[N-n-propyl-N-(3- } \\
\text { sul-fopropyl)-amino]-phenol disodium salt } \\
\text { dihydrate }\end{array}$ \\
Tiron & $\begin{array}{l}\text { 4,5-Dihydroxy-1,3-benzenedisulfonic acid } \\
\text { disodium salt }\end{array}$ \\
DPKBH & Di-2-pyridyl ketone benzoylhydrazone \\
DPFTH & 2,2'-Dipyridyl-2-furancarbothiohydrazone \\
TLCR & 4-(2-Thiazolylazo)-6-chlororesorcinol \\
\hline
\end{tabular}

